\title{
CO-DIGESTION OF CULTIVATED MICROALGAE AND SEWAGE SLUDGE FROM MUNICIPAL WASTE WATER TREATMENT
}

\author{
Olsson, J. ${ }^{1}$, Shabiimam M.A. ${ }^{1}$, Nehrenheim E. ${ }^{1}$, Thorin, $E^{1}$ \\ ${ }^{1}$ School of Sustainable Development of Society and Technology, Mälardalen University, P O Box 883, SE-721 23 Västerås, Sweden
}

\begin{abstract}
The demand for biogas is continuously growing and the biogas substrate, such as food waste, may soon become limited and it is therefore important for biogas producers to expand the range of substrates. One way can be to use microalgae in co-digestion with sewage sludge.

The present study explores the possibilities to use harvested microalgae from Lake Mälaren, as a co-substrate to sewage sludge in biogas production under mesophilic and thermophilic conditions. The aim is to investigate if codigestion of microalgae and sewage sludge is more efficient for biogas production compared using the sludge alone. The study has been carried out as a BMP-experiment (Biochemical Methane Potential) in batch fermentation bottles. The substrate was undigested sludge where $0 \%, 12$ $\%, 25 \%$ and $37 \%$ were replaced with the cultivated microalgae. The results showed that the use of an algae/bacteria community, cultivated in prior to digestion, can serve as a biomass substrate for biogas production together with municipal wastewater sludge. Co-digestion of microalgae and sewage sludge can be more efficient for biogas production compared to using the sludge alone under mesophilic conditions. It can also be concluded that thermophilic co-digestion between the microalgae and sludge give lower biochemical methane potential.
\end{abstract}

Keywords: biogas production; co-digestion; microalgae cultivation; sludge

\section{NOMENCLATURE}

$\begin{array}{ll}\text { Abbreviation } & \\ \text { BMP } & \text { Biochemical Methane Potential } \\ \text { TSS } & \text { Total Suspended Solids } \\ \text { TS } & \text { Total solids } \\ \text { VS } & \text { Volatile solids }\end{array}$

\section{INTRODUCTION}

Anaerobic digestion of sludge from municipal wastewater treatment is among the oldest processes used for stabilization of solids and biosolids. The digestion involves the decomposition of organic matter in the absence of oxygen with a production of methane gas.

This burnable gas can be upgraded to a fuel that can support busses, taxis and regular cars. Biogas is an environmentally friendly fuel and the expansion of biogas production systems will be an important contribution to the global conversion from fossil to renewable energy systems (Metcalf \& Eddy, 2002). Since the demand for biogas is continuously growing in the society and the biogas substrate, for example food waste, may soon become limited it is important for municipal wastewater treatment plants to enhance their biogas production as much as possible. One way to do this is to use microalgae as a substrate in the digestion process and co-digest it with the sewage sludge. A cost efficient method is to cultivate the algae in a treatment step of photo bioreactors for waste water or nutrient rich reject water from centrifuges that dewater the sludge from the waste water treatment plant. In this way a simultaneous nutrient recovery, water treatment and biomass production can be achieved. Successful cultivation of microalgae in waste water has been shown in recent studies (Odlare et al. (2011); Su et al. (2011).

The process with cultivation of microalgae form reject water has been evaluated by Rusten and Sahu (2011), in this study, it wasconcluded to be possible to utilize nutrients form sludge liquor, natural light, and $\mathrm{CO}_{2}$ from biogas to grow microalgae at the wastewater treatment plant. The microalgae will remove nitrogen and phosphorous from the reject water, reducing the impact of returning side streams to the head of the treatment plant.

Co-digestion of sewage sludge with macroalgae has been made by Cecchi et al. (1996). In this study it was concluded that the mesophilic $\left(37^{\circ} \mathrm{C}\right)$ co-digestion is applicable with potentialities of $30 \%$ of present TSS-flow rate. Thermophilic $\left(55^{\circ} \mathrm{C}\right)$ co-digestion is not possible, because of the inhibition of methanogens due to the activity of sulphate -reducing microorganisms according to Cecchi et al. (1996). Codigestion with food-waste and different additional amounts of microalgae has been studied by Nehrenheim et al. (2012). Increased production of biogas as well as the increased proportion of methane when algae were codigested with sewage sludge were shown. 
The use of co-digestion of substrates in order to stabilize the digestion process by improving the $\mathrm{C} / \mathrm{N}$-ratio has been mentioned by several authors ;(Brune et al., 2009, Khalid et al., 2011, Mata-Alvarez et al., 2011). Especially for algae biomass it has been pointed out that the anaerobic digestion is limited by high $\mathrm{N}$ content (Brune et al., 2009, Wiley et al., 2011) and sludge has been suggested as suitable co-digestion substrate. Brune et al. (2009) conclude that co-digestion of algae biomass residues and fat, oil and grease waste can give improved methane yields and reactor productivity. González-Fernández et al. (2011) investigated co-digestion of swine manure with algae biomass but did not find any increase in methane production. The explanation for this conclusion was that the used algae (Chlorella vulgaris and Scenedesmus obliquus) have hemicellulosic cell walls which are resistance to bacterial degradation and that pre-treatment prior to the digestion is necessary. However, swine manure is not either a high carbon substrate. Wiley et al. (2011) refer to earlier work indicating that thermophilic conditions are beneficial for digestion of algae due to reducing the resistance of the cell wall.

This paper explores the possibilities to use harvested microalgae from lake Mälaren, as a co-substrate to sewage sludge in biogas production under mesophilic and thermophilic conditions. The aim is to investigate if codigestion of microalgae and sewage sludge is more efficient for biogas production compared to using the sludge alone. The hypothesis is that easy available carbon and the extra nutrients added by the microalgae will give a higher biogas production.

\section{MATERIALS AND METHODS}

\subsection{Microalgae cultivation}

Lake water was collected from Lake Mälaren mid June 2012. The water was used the same day in the experiment, without any prior preservation or storage. A batch experiment was set up with two $120 \mathrm{dm}^{3}$ glass aquariums each containing $10.5 \mathrm{dm}^{3}$ lake water and $21.5 \mathrm{dm}^{3}$ tap water. $3.5 \mathrm{dm}^{3}$ of the nutrient mix Jaworski's medium (table 1) was added to each aquarium in order to ensure sufficient growth of microalgae (Odlare et al., 2011) for harvesting and utilization in the co-digestion experiment. Similar Jaworski's medium was found efficient as nutrient media in the algae cultivation experiment by Odlare et al., 2011. The aquariums were placed in a room with consistent light. The light intensity was 7000 lux $\left(100 \mu \mathrm{mol}\right.$ photons $\left./ \mathrm{m}^{2}, \mathrm{~s}\right)$ in the beginning of the cultivation period.

Figure 1 shows the cultivated microalgae in the aquariums on the 9 of july 2012. 20 days after startup of the cultivation the algae were harvested. The content of total solids (TS) and volatile solids (VS) in the algae slurry was measured by an external laboratory according to Swedish standard (SS 0281 13) (SIS, 1981). The result of the measurement was 6.05 TS\% and $51.0 \mathrm{VS} \%$ for the cultivated microalgae (Average values from duplicates).

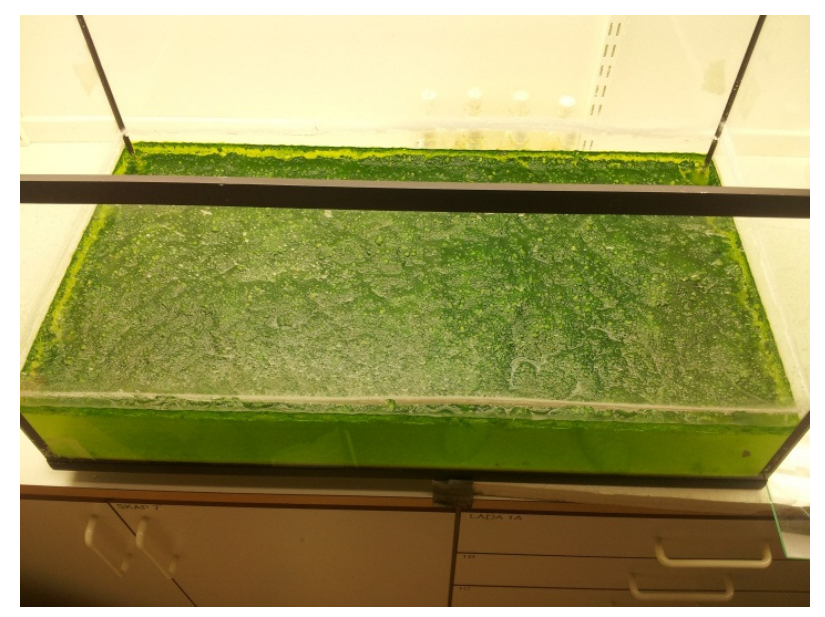

Figure 1 Aquarium with cultivated microalgaes

Table 1 Composition of Jarowskis Medium, nutrient mix used for cultivation of microalgae.

\begin{tabular}{|c|c|c|}
\hline No & Stocks & Every $200 \mathrm{~cm}^{3}$ \\
\hline 1 & $\mathrm{Ca}\left(\mathrm{NO}_{3}\right)_{2} * 4 \mathrm{H}_{2} \mathrm{O}$ & $4.0 \mathrm{~g}$ \\
\hline 2 & $\mathrm{KH}_{2} \mathrm{PO}_{4}$ & $2.48 \mathrm{~g}$ \\
\hline 3 & $\mathrm{MgSO}_{7} * \mathrm{H}_{2} \mathrm{O}$ & $10.0 \mathrm{~g}$ \\
\hline 4 & $\mathrm{NaHCO} 3$ & $3.18 \mathrm{~g}$ \\
\hline \multirow[t]{2}{*}{5} & EDTAFeNa, & $0.45 \mathrm{~g}$ \\
\hline & EDTANa $_{2}$ & $0.45 \mathrm{~g}$ \\
\hline \multirow[t]{3}{*}{6} & $\mathrm{H}_{3} \mathrm{BO}_{3}$ & $0.496 \mathrm{~g}$ \\
\hline & $\mathrm{MnCl}_{2} * 4 \mathrm{H}_{2} \mathrm{O}$ & $0.278 \mathrm{~g}$ \\
\hline & $\left(\mathrm{NH}_{4}\right) 6 \mathrm{Mo}_{7} \mathrm{O}_{24} * 4 \mathrm{H} 2 \mathrm{O}$ & $0.20 \mathrm{~g}$ \\
\hline \multirow[t]{3}{*}{7} & Cyanocobalamin & $0.008 \mathrm{~g}$ \\
\hline & Thiamine $\mathrm{HCl}$ & $0.008 \mathrm{~g}$ \\
\hline & Biotin & $0.008 \mathrm{~g}$ \\
\hline 8 & $\mathrm{NaNO}_{3}$ & $16.0 \mathrm{~g}$ \\
\hline 9 & $\mathrm{Na}_{2} \mathrm{HPO}_{4} * 12 \mathrm{H} 2 \mathrm{O}$ & $7.2 \mathrm{~g}$ \\
\hline
\end{tabular}

\subsection{Undigested sludge and inoculums}

Undigested sludge was collected from the municipal wastewater treatment plant in Västerås, central Sweden simultaneously as the harvesting of microalgae in the aquariums (on the same day). The substrate to be codigested with algae in the experiment was undigested wastewater treatment sludge. This is a mixture of primary sludge from the pre sedimentation, biosludge from the biological treatment and chemical sludge from the chemical treatment. The sample was taken directly after the sedimentation step of the mixed sludge. The inoculum used 
in the test is sludge after the digesters at the waste water treatment plant. In this particular facility mesophilic digestion at $37{ }^{\circ} \mathrm{C}$ is applied for the stabilization of sludge. The content of total solids (TS) and volatile solids (VS) in the substrate and the inoculum was measured by an external laboratory according to the standard SS 028113 (SIS, 1981). The results of the measurement were for the substrate 6.75 TS\% and $54.2 \mathrm{VS} \%$ and for the inoculum $2.70 \% \mathrm{TS}$ and $54.1 \%$.

\subsection{Biochemical methane potential (BMP) tests}

This study has been carried out as a BMP-experiment in batch fermentation bottles and the production of biogas was measured during a 35 day fermentation period. BMP-tests were developed to get an easy and reliable analytical method to decide the digestions possibility and methane potential of an organic material (Carlsson and Schnürer, 2011). Today these batch tests are used frequently to evaluate different substrates at Swedish and international universities and institutes. In the literature there are guidelines and protocols about how a BMP-test should be executed in this study the guidelines by Carlsson \& Schnürer, 2011 have been followed. .

The batch experiment of biogas production was conducted in $1 \mathrm{dm} 3$ conical bottles under mesophilic condition (Figure 2) and in $0.1 \mathrm{dm} 3$ conical bottles in thermophilic condition. All batches were replicated three times according to Table 2. Total working volume of fermented material in each flask was $700 \mathrm{~cm} 3$ for the mesophilic BMP-test and the amount of added inoculum was $4.2 \mathrm{~g}$ VS (corresponding to $6 \mathrm{~g} / \mathrm{dm} 3$ ). The total working volume, in the thermophilic BMP-test, of fermented material in each flask was $70 \mathrm{~cm} 3$ and the amount of added inoculum was $0.42 \mathrm{~g}$ VS (corresponding to $6 \mathrm{~g} / \mathrm{dm} 3$ ). Eight treatments were prepared by replacing $0 \%, 12 \%, 25 \%$ and $37 \%$ of undigested sludge with the cultivated microalgae under mesophilic and thermophilic conditions, as shown in Table 2. A reference group, containing only inoculum, was run in parallel to obtain the background biogas production (Bottles 1-3 and 16-18). The bottles were closed with butyl rubber stoppers and aluminum crimps. The temperature was held at $37 \stackrel{\circ}{\circ}$ in the mesophilic experiment and $55 \stackrel{\circ}{\circ}$ in the thermophilic experiment. Gentle stirring with a speed of approximately $130 \mathrm{rpm}$ was applied during the whole test (Orbital shaker 4536).

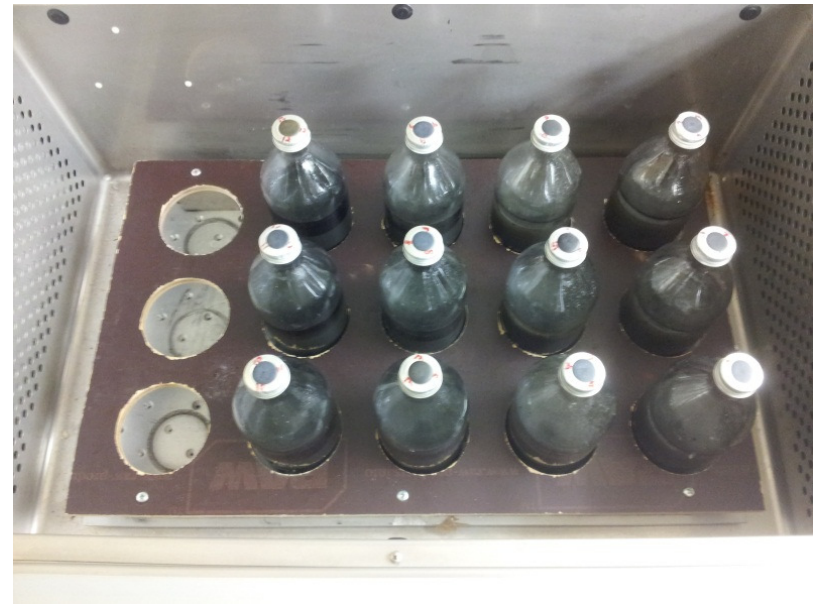

Figure 2 Bottles in the BMP-experiment

Table 2 Arrangement on batch fermentation experiment of biogas production

\begin{tabular}{|c|c|c|c|c|c|c|c|}
\hline \multirow[b]{2}{*}{ 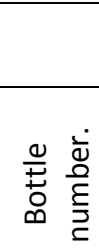 } & \multirow[b]{2}{*}{ 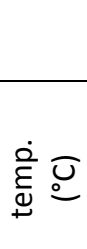 } & \multirow[b]{2}{*}{ 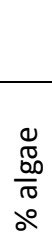 } & \multirow[b]{2}{*}{$\begin{array}{l}\stackrel{0}{0} \\
\frac{0}{0} \\
\frac{5}{n} \\
0\end{array}$} & \multicolumn{2}{|c|}{ Microalgae } & \multicolumn{2}{|c|}{$\begin{array}{l}\text { Undigested } \\
\text { sludge }\end{array}$} \\
\hline & & & & $\curvearrowright \frac{\tilde{m}}{\frac{\tilde{\varepsilon}}{0}}$ & $\sum_{\infty}^{n}$ & $\curvearrowright \frac{\widetilde{m}}{\frac{m}{0}}$ & $\sum_{\infty}^{n}$ \\
\hline $4-6$ & 37 & 0 & 100 & 0 & 0 & 3.00 & 2.10 \\
\hline $7-9$ & 37 & 12 & 88 & 0.36 & 0.25 & 2.64 & 1.85 \\
\hline $10-12$ & 37 & 25 & 75 & 0.76 & 0.53 & 2.24 & 1.57 \\
\hline $13-15$ & 37 & 37 & 63 & 1.12 & 0.78 & 1.89 & 1.32 \\
\hline $19-21$ & 55 & 0 & 100 & 0 & 0 & 3.00 & 0.21 \\
\hline $22-24$ & 55 & 12 & 88 & 0.36 & 0.025 & 2.64 & 0.185 \\
\hline $25-27$ & 55 & 25 & 75 & 0.76 & 0.053 & 2.24 & 0.157 \\
\hline $28-30$ & 55 & 37 & 63 & 1.11 & 0.078 & 1.89 & 0.132 \\
\hline
\end{tabular}

\subsection{Analysis of gas production and quality}

The gas production was measured by monitoring the pressure increase in the bottles with a pressure meter (GMH 3161-13). Every time the pressure in the bottles exceeded 250 mbar samples were taken from the headspace in each bottle for methane analysis in the biogas. The methane analysis was conducted by using gaschromatography (PerkinElmer Arnel Clarus 500, column 7' HayeSep N 60/80, 1/8" SF; FID detector $250{ }^{\circ} \mathrm{C}$; carrier gas: helium, flow $31 \mathrm{~cm} 3 / \mathrm{min}$, temp injector $60{ }^{\circ} \mathrm{C}$, test injection with a headspace sampler Turbo Matrix 110)

The measured values of the total biogas pressure at every measurement together with the knowledge of the gas volume in the headspace and temperature in the bottles were then used to determine the amount of produced biogas with the ideal gas law (Equation 1). Since each bottle has the same amount of sludge $(700 \mathrm{~cm} 3)$ the headspace volume is equal between the bottles. 
The produced biogas was related to the amount VS added to every bottle and was recalculated in $\mathrm{Ncm}^{3}$ (normal standard), i.e. at atmospheric pressure and at $0^{\circ} \mathrm{C}$. The amount of methane $\left(\mathrm{CH}_{4}\right)$ in each sample was measured and implemented in the calculation and the results were then presented as $\mathrm{Ncm}^{3} \mathrm{CH}_{4} / \mathrm{g}$ VS. The methane production from the reference bottles was taken away from the total production in the other bottles. The result presented in the next section is the production of methane only from substrate (undigested sludge and cultivated algae).

$n=\frac{p^{*} V}{R * T}$

$\mathrm{n}=\mathrm{mol}$ biogas at each measurement $(\mathrm{mol})$

$\mathrm{p}=$ total pressure at each measurement (measured + atmospheric pressure) (mbar)

$V=$ headspace in the bottles $(\mathrm{cm} 3)$

$\mathrm{T}=$ Temperature at each measurement $\left({ }^{\circ} \mathrm{K}\right)$

$\mathrm{R}=$ The gas constant $(8.314 \mathrm{Jmol}-1 \mathrm{~K}-1)$

\section{RESULTSAND DISCUSSION}

Table 3 shows the results of the BMP-tests after 35 days digestion. The gas yield varies between the different BMPbottles with the same amount of microalgae in the substrate. Nevertheless, even with this deviation a difference in gas production between the bottles with different amounts of algae can be identified. The biogas production in the mesophilic conditions was improved with $12 \%$ for the bottles with $12 \%$ microalgae and $88 \%$ sewage sludge compared with the bottles with $100 \%$ sludge as a substrate. In the bottles with $25 \%$ and $37 \%$ microalgae the biogas production was slightly reduced compared with the bottles where only sludge was used. Under thermophilic conditions the biochemical methane potential was reduced when the microalgae were added. This confirms the experiments with macroalgae made by Cecchi et al. (1996) where co-digestion was not possible in thermophilic conditions because of the inhibition of methanogens due to the activity of sulphate-reducing microorganisms.
Table 3 Biochemical methane potential of the algae and sewage sludge after 35 days of incubation

\begin{tabular}{|c|c|c|}
\hline & $\begin{array}{r}\text { Total accumulated methane production } \\
\left(\mathrm{Ncm}^{3} \mathrm{CH}_{4} / \mathrm{g} \text { VS) }\right.\end{array}$ \\
\hline Treatment & $\begin{array}{c}\text { Mesophilic } \\
\text { digestion }\end{array}$ & $\begin{array}{c}\text { Thermophilic } \\
\text { digestion }\end{array}$ \\
\hline $0 \%$ algae & $276 \pm 29$ & $112 \pm 22$ \\
\hline $12 \%$ algae & $309 \pm 46$ & $109 \pm 29$ \\
\hline $25 \%$ algae & $274 \pm 27$ & $86 \pm 45$ \\
\hline $37 \%$ algae & $270 \pm 114$ & $75 \pm 49$ \\
\hline
\end{tabular}

Methane production curves are often divided into three stages: Lag phase, decomposition phase and flattening phase (Carlsson \& Schnürer, 2011).The lag phase is the time from the start of the experiment to the start of the methane production in the bottles. It can be seen in Figure 3 that there is no lag phase for the bottles with only sewage sludge, $12 \%$ algae, and $25 \%$ algae but a short lag phase for the bottles with $37 \%$ algae.

It seems that with a high content of microalgae the microorganisms in the inoculum are disturbed and need time to adjust to the new environment. If micoalgaes will be used in a full scale mesophilic digestion plant it might therefore be important not to change the relationship between sewage sludge and microalgaes to fast and too much since this might cause a reduction of gas production for a period of time.

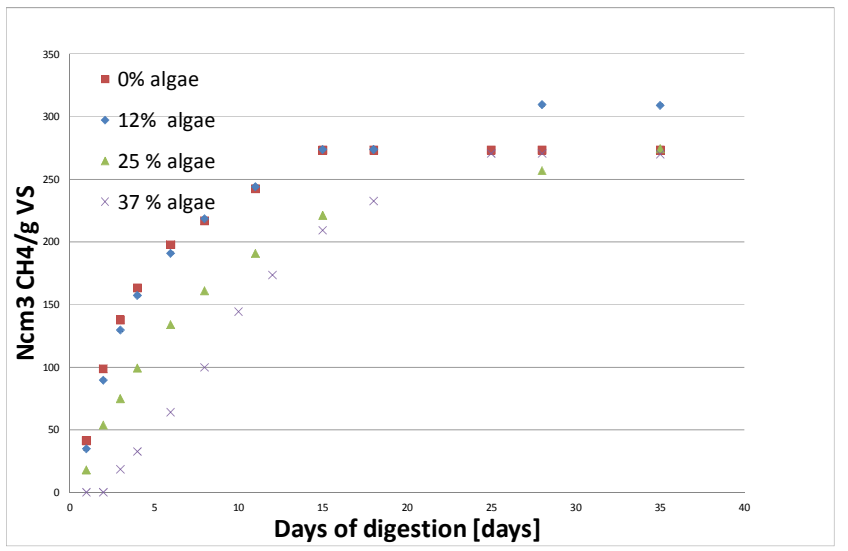

Figure 3 Methane potential per gram VS for untreated substrates $0,12,25,37 \%$ algae at mesophilic conditions 


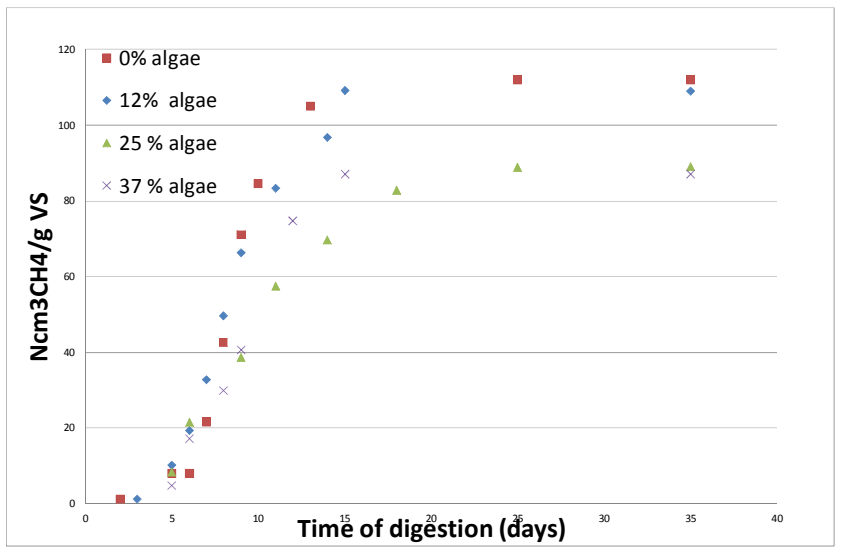

Figure 4 Methane potential per gram VS for untreated substrates $0,12,25,37 \%$ algae at mesophilic conditions

In thermophilic conditions (shown figure 4) there is a lag phase in all the bottles. The reason for this phenomenon is because the inoculum is taken from a mesophilic digester. The microorganisms have to be adapted to the new temperature conditions before the methane production can start. If the experiment will be redone it would be advisable to use an inoculum from a thermophilic digestion for the bottles that will be in thermophilic conditions.

According to figure 3 the decomposition phase in mesophilic conditions is slower for the bottles with high compositions of microalgae. This can indicate that the organic material in sewage sludge is more easily biodegraded than the organic material in microalgae. If Figure 3 and 4 is compared the decomposition phase as expected is much faster under thermophilic conditions than under mesophilic conditions. This faster decomposition phase of sewage sludge under thermophilic digestion is a well-known conclusion and has been shown by Buhr and Andrews (1977).

\section{CONCLUSIONS}

The results from this study showed that the use of an algae/bacteria community, cultivated in lakewater, can serve as a biomass substrate for biogas production together with municipal wastewater sludge. Co-digestion of microalgae and sewage sludge can be more efficient for biogas production compared using the sludge alone under mesophilic conditions and with $12 \%$ micro algae and $88 \%$ sewage sludge. It can also be concluded that thermophilic co-digestion of microalgae and sewage sludge gives a lower biochemical methane potential compared to sewage sludge alone.

The lower biochemical methane potential of higher share of microalgae in the sewage sludge $(25 \%$ and $37 \%)$ can be explained by the high content of nitrogen $(N)$ in algae biomass, creating a toxic environment due to high ammonia concentration, a phenomenon found both in mesophilic and thermopilic condition.

\section{ACKNOWLEDGEMENT}

This research has been performed in close collaboration with the end user of the studied system, as a co-production study within the framework of the ACWA-project and the VA-cluster Mälardalen. Most significantly, Purac $A B$ and Mälarenergi $A B$ should be thanked for their funding, knowledge and development contributions in the study. Further, the authors would like to thank the Knowledge Foundation in Sweden (KKS) for their financial support in such important co-productive research. Last but not least, we would like to highlight the contribution of the laboratory at JTI regarding the chromatography analysis.

\section{REFERENCE}

BRUNE, D. E., LUNDQUIST, T. J. \& BENEMANN, J. R. 2009. Microalgal biomass for greenhouse gas reductions: Potential for replacement of fossil fuels and animal feeds. Journal of Environmental Engineering, 1136-1144.

BUHR, H. O. \& ANDREWS, J. F. 1977. The thermophilic anaerobic digestion process. Water Res, 11, 129143.

CARLSSON, M. \& SCHNÜRER, A. 2011. RAPPORT U2011:12 - Handbok metanpotential Avfall Sverige utveckling.

CECCHI, F., PAVAN, P. \& MATA-ALVAREZ, J. 1996. Anaerobic co-digestion of sewage sludge: Application to the macroalgae from the Venice lagoon. Resources, Conservation and Recycling, 17, 57-66.

GONZÁLEZ-FERNÁNDEZ, C., MOLINUEVO-SALCES, B. \& GARCÍA-GONZÁLEZ, M. C. 2011. Evaluation of anaerobic codigestion of microalgal biomass and swine manure via response surface methodology. Applied Energy, 88, 3448-3453.

KHALID, A., ARSHAD, M., ANJUM, M., MAHMOOD, T. \& DAWSON, L. 2011. The anaerobic digestion of solid organic waste. Waste Management, 31, 17371744.

MATA-ALVAREZ, J., DOSTA, J., MACÉ, S. \& ASTALS, S. 2011. Codigestion of solid wastes: A review of its uses and perspectives including modeling. Critical Reviews in Biotechnology, 31(2):99-111.

METCALF \& EDDY, I., GEORGE TCHOBANOGLOUS, FRANKLIN L BURTON 2002. Wastewater Engineering: Treatment and Reuse, 4th ed, McGraw \& Hill

NEHRENHEIM, E., ODLARE, M., LIU, X. \& LI, S. 2012. Co-digestion of cultivated microalgae and food waste. Submitted to Appl Energ 2012.

ODLARE, M., NEHRENHEIM, E., RIBÉ, V., THORIN, E., GAVARE, M. \& GRUBE, M. 2011. Cultivation of algae with indigenous species - Potentials for 
regional biofuel production. Applied Energy, 88, 3280-3285.

RUSTEN, B. \& SAHU, A. 2011. Microalgae growth for nutrient recovery from sludge liquor and production of renewable bioenergy. Water science and technology, 64, 1195-1201.

SIS 1981. Determination of dry matter and ignition residue in water, sludge and sediment. Kemiska vattenundersökningar, SIS/TK 424, 3 .

SU, Y., MENNERICH, A. \& URBAN, B. 2011. Municipal wastewater treatment and biomass accumulation with a wastewater-born and settleable algalbacterial culture. Water Research 45 (2011) 33513358.

WILEY, P. E., CAMPELL, J. E. \& MCKUIN, B. 2011. Production of biodiesel and biogas from algae: A review of process train options. Water Environmental Research, 82(4): 326-338. 